\title{
BACKGROUND FOR PHYTOTECHNOLOGIES APPLIED AT MULTIMETAL CONTAMINATED SITES IN UKRAINE
}

\author{
Lidija Svirenko \\ Kharkiv State Academy of Municipal Economy, Kharkiv, Ukraine
}

Alevtina Nossova

Enterprise 'Priroda' Ltd., Lugansk, Ukraine

\begin{abstract}
Ukraine is a country with a great diversity of natural conditions, developed agriculture and industrial sectors such as mining, metallurgy, machinery and chemical branches. The use of outdated technologies has resulted in landscape degradation and environment contamination. Sites with the dangerous level of contamination located at rivers' floodplain in industrial centers, near the spoil banks, especially buming, landfills, grounds for sludge and dredged sediment damping. Leachate from municipal waste damp is a source of environment pollution. For multi-metal contaminated sites, the treatment with phytotechnologies is proposed as a low cost and environmentally friendly alternative. Willows are discussed as local plants for phytostabilization. Plants - hyperaccumulators could be found in Ukraine too and are used in the application of phytotechnologies. Experimental work has to be done before the technique could be applied in situ.
\end{abstract}

\section{KEYWORDS:}

Contaminated soils, floodplain, spoil bank, landfill, leachate, sewage sludge, dredged sediments, metal up-taking, hyper-accumulator, willow, phytotechnology. 


\section{INTRODUCTION: GEOGRAPHY, ECONOMY AND ENVIRONMENT OF UKRAINE IN BRIEF}

Ukraine is one of the largest countries in Europe with an area of $603,000 \mathrm{~km}^{2}$ and the population of about 48 million. Average density of the population is about 83 inhabitants/ $\mathrm{km}^{2}$ and can reach up to 490 inhabitants $/ \mathrm{km}^{2}$. The country has a favourable climate and abundant natural resources.

The country has a great diversity of natural conditions and landscapes. One can see mixed deciduous forests, steppes with rich grassy vegetation, solonchaks, mountains and marine coasts of the Black and Azov Seas.

Different types of soils are characteristic for different geographical zones. Chernozems and grey forest soils are well developed in the forest-steppe; chernozems and kashtanozems are in the steppe zone, and podzolic and soddy-podzolic soils are in the zone of mixed forests [1,2].

Ukraine is a country with developed agriculture and industrial sectors. Industrial complex includes mining, metallurgy, machinery and chemical branches. The eastern and central parts of the country are more industrialized. Main sources of energy are power and nuclear stations.

Outdated technologies which are used especially in mining and municipal waste treatment have caused landscape degradation in numerous sites of the country and soils, sediments and water contamination by metals and others pollutants.

\section{MATERIALS AND METHODS FOR CONTAMINATED LAND CHARACTERISTICS}

Concentration of chemical elements in certain areas of the Earth depends on natural factors and a profile of the technogenic activity in the region. Natural factors provide the elements' content considered as background for the region, and human activity both domestic and industrial can result in accumulation of trace elements.

It has been recognized that the effects of a certain trace element on a particular organism including human being depend on the concentration of the element. Usually the soils contaminated by technogenic activity contain a set of elements with a high concentration producing an integrated effect on human health. A special method of approximation was used to estimate the level of soils contamination and their dangerous effect on human health [3]. Actual metal concentrations were compared to the regional background, and the coefficient of concentration $K_{c i j}$ was calculated for each $i$-th metal element in each $j$-th sample. A cumulative soil contamination index $Z_{c j}$ was calculated for each $j$-th sample according [4]. The latter coefficient was used as a measure of soil contamination hazard level. According to the current sanitary standards in Ukraine, there are four hazard levels: permissible, moderately dangerous, dangerous, and extremely dangerous.

To assess the rates of metal transfer from environment to the plants, specific coefficients of accumulation $K_{a i j}$ were calculated. The latter coefficient is various for different plant 
species. According to plants ability to uptake trace metal and elements from soils and sediments, plant species could be divided onto hyper-accumulators, accumulators, indicators and excluders $[5,6,7]$.

\section{TYPICAL PATTERNS OF METAL-CONTAMINATED SITES IN INDUSTRIAL REGIONS}

Industrial activity, coal mining branch and domestic waste in the urban territories are of considerable significance for soils, land and sediment contamination in the country. The increase of the metals concentration in soils and the level of hazard of the pollution could be shown with the examples of some sites in the Eastern Ukraine which is the most industrialized part of the country with the highly affected environment.

\subsection{River floodplains of industrial centers (case study of the city of Kharkiv)}

Kharkiv is the second nation's largest city located on a rolling plain in the Forest-Steppe zone in the North-Eastern Ukraine. Four small rivers and several gullies of the Siverskij Dinets catchment area intersect its area. In the industrial profile of the city machinery, instrument-making, and experimental plants of physics and technology research institutes are dominant. Extensive vehicle and railroad traffic, as well as industrial and household solid wastes accumulation contribute to overall geochemical impact on the urban environment. Historically, most of the industries were located along the rivers although now they are no longer used as sources for industrial and household water supply and are sinks for pollutants coming with discharge of treated waste waters and untreated urban runoff. River valleys provide a suitable model for studying pollutant accumulation reflecting geochemical properties of the catchment areas. Characteristic metal contaminants of river floodplains are such elements as $\mathrm{Cd}, \mathrm{Zn}, \mathrm{Cr}, \mathrm{Co}, \mathrm{Mn}, \mathrm{Ni}, \mathrm{Pb}$. Most of the metal elements were concentrated in the rates higher than their regional background concentrations. For the majority of the locations, soil contamination level was assessed as moderate to very hazardous [8].

For sampled vegetation, in all river basins both nettle and willow to highest extend concentrated $\mathrm{Sr}$ (average $K_{a}$ ranged from 4.64 to 10.79 and from 6.73 to 11.28 , respectively) except the only river floodplain where the most accumulated element was $\operatorname{Cr}(\mathrm{Ka} 10.26$ and 7.25 , respectively). Other elements accumulated in plants comparing to soils were $\boldsymbol{M o}$ (1.35-3.83), $\boldsymbol{Z n}$ (1.27-1.42, except the Kharkiv River) and $\boldsymbol{P b}$ in the Udy river's floodplain. Metal content patterns have strongly positively correlated in the both species [8].

As urban river valleys in the city are used mostly for recreation and urban household scaled agriculture, the levels of soil contamination are dangerous for human and ecosystem health and therefore, the soils need rehabilitation.

\subsection{Territories of settlements in coal mining areas (case study of the town Roven'ky)}

Roven'ky is the town belonged to Luganskaja Oblast' and is located in the coal mining Donbass Region just in the east of the country, in the Steppe zone. The first mines appeared here at the end of $19^{\text {th }}$ century. Coal mining development fostered a very fast 
KALMAR ECO-TECH'03

Bioremediation and Leachate Treatment

KALMAR, SWEDEN, November 25-27, 2003

growth of the town Roven'ky and formed its mosaic structure consisted of mines, spoil banks, other industrial areas, plots of agriculture lands situated in the border of the currently inhabited zone $[2,9]$.

Environment of the settlements that border the mines and damped waste is strongly affected by industrial activity, especially because of the pollutants' emission from a burning spoil bank situated sometimes at the distance of $150 \mathrm{~m}$ from houses. The sulfur content in coal can be determined as medium $(1,1-3 \%)$, so precipitation infiltrated through spoil wastes body has transformed into acid liquid to affect surface and shallow water. Spoil banks of the most abandoned mines have not been reclaimed till now [10].

The lands near a mine in Dzerzshinsky settlement were sampled and the content of 20 metals in the soils of the settlement has been analyzed by the research center "Vostok GRGP, Lugansk". Some of the concentrations of metals (total, $\mathrm{mg} / \mathrm{kg}$ ) vary as follows: $\mathrm{Hg}-0,15-1,3 ; \mathrm{As}-25,5-90 ; \mathrm{Zn}-103,5-303,6 ; \mathrm{Pb}-30,1-79,5 ; \mathrm{Cr}-199,5 ; \mathrm{Ni}-69$; $\mathrm{Co}-$ 19,8-29,7; $\mathrm{Ba}-510-3009 ; \mathrm{Li}-76,5-103,5$. Therefore, the level of the inhabited zone contamination could be defined as dangerous and very dangerous (integrated index $Z c$ is more 32 and reaches 349 near the industrial zone,) [9].

\subsection{Sites for domestic solid wastes damping (closed landfills and damps Derkatchy $\&$ Rogan, in the suburbs of the city of Kharkiv)}

The Derkachy landfill is situated to the North of Kharkiv near the small town Derkachy at the bottom of the hollow within $3 \mathrm{~km}$ from the Lopan River. The sqaure of the landfill is $11,7 \mathrm{ha}$, it has been in exsploitation since 1975 and is to be closed in the nearest time. At its foot there is a pond for leachate collection which is expected to be pumped and transported to a sewage treatment work.

The Rogan damp locates at the east of the city in the basin of the small Roganka River. The damp with the surface square of about 3,6 ha has been closed seven years ago without rehabilitation of the site in a proper way. On the lower slope along the relief there is cascade of small ponds to collect leachate from wastes damp. At the moment there is no treatment of liquid from the ponds and it just penetrates into the soils of the valley.

Both Derkachy and Rogan waste damping sites are the sources of environment pollution now. Thus, the content of metals in the soils on the border of a sanitary zone is essentially higher than basic ones (total, $\mathrm{mg} / \mathrm{kg}$ ): $\mathrm{Cd}-0,5-5,5 ; \mathrm{Zn}-80-330 ; \mathrm{Ni}-25-60$; $\mathrm{Co}$ - 16-40; Mn - 380-840; Cu - 27-66; Cr - 50-150; Pb - 25-35; Li - 13-27; Sn -7-10; F $-290-400$.

The variation of leachate characteristics is as follows (Derkatchy \& Rogan):

Acidity - pH 5,9-11,6; $\mathrm{BOD}_{5}-41-15$ 000; COD 50-35 000; chlorides -36-126 300mg/1; sulphates - 18-14 968mg/l; nitrates - 0,1-14 775mg/l; nitrogen total - 1-2 892mg/l; phenol - 0,01-350mg/l; chlorinated organic chemicals - $44-292000 \mathrm{mkg} / \mathrm{l}$; metals, $\mathrm{mkg} / \mathrm{l}: \mathrm{As}-2-240 ; \mathrm{Cd}-0,2-2000 ; \mathrm{Hg}-0,17-50 ; \mathrm{Cu}-1,3-8000 ; \mathrm{Ni}-14,2-$ 30000; $\mathrm{Zn}-20-27242$. 


\subsection{Sites for sewage sludge dewatering and drying (Dykanivka \& Bezludivka waste water treatment plants, Kharkiv)}

Sewage sludge is a product of both domestic and industrial waste water treatment. It is rich in organic matter and nutrients (nitrogen and phosphates) but sometimes can contain high level of different metals that makes soil toxic to plants. Therefore, sewage sludge could not be recommended for agricultural soils dressing and it is accumulating on the grounds of Bezludivka treatment plant for dewatering. Dried sludge dispersed by wind can effect neighboring agricultural land and sites for recreation in the valley of the Udy River. Infiltrate from the site of sewage sludge damping is a factor of shallow water pollution.

The content of soluble form of trace elements and metals, $\mathrm{mg} / \mathrm{kg}$ is: $\mathrm{Cd}-26-41 ; \mathrm{Zn}-$ 500-900; $\mathrm{Ni}-70-250 ; \mathrm{Co}-0,85-2,00 ; \mathrm{Mn}-42-113 ; \mathrm{Cu}-14-250 ; \mathrm{Cr}-12,5-19,5 ; \mathrm{Pb}-$ $3,2-6,0 ; \mathrm{F}-2,17-18,9$.

Total concentration of some metals in dried sludge is as follows, mg/ kg: $\mathrm{Zn}-150 ; \mathrm{Cu}-$ $50 ; \mathrm{Cr}-1000 ; \mathrm{Pb}-70 ; \mathrm{Ba}-2000 ; \mathrm{Sn}-70 ; \mathrm{Be}-2 ; \mathrm{Bi}-1 ; \mathrm{Ag}-1$.

\subsection{Sites for dredged sediments damping}

Alluvium accumulated on the bed of rivers intersecting urbanized areas is polluted by organic and non-organic substances carried from watershed by surface water [11, 12]. Initial analyses of river sediments in Kharkiv show that they are significantly contaminated with heavy metals $(\mathrm{Zn}, \mathrm{Cu}, \mathrm{Ag}, \mathrm{Sn}, \mathrm{Cr}$ and others), especially in the borders of old buildings. Sediment thickness reaches up to $3 \mathrm{~m}$.

To improve draining ability of the rivers in the center of Kharkiv, municipal authorities are expected to provide the river's bed cleaning. Since 2003 dredging would be carried with using dredger pump.

Sites of river sediments damping after river's bed cleaning in Kharkiv would become the sources of environment contamination and have to be treated in a proper way using phytotechnologies

\section{PLANTS FOR METAL CONTAMINATED LAND TREATMENT}

Treatment of contaminated sites like waste damp is expected by using of multi-layers cover according to the regulations in Ukraine. This method is very expensive and it is very rare in practice due to the poor budget of the country.

Preferences could be made to phytotechnologies as they are cheaper and environmentally friendly. An important element of phytotechnology development is a plant selection. The usage of local plants in phytotechnology application is preferred in certain regions. Willow (Salix spp.) is a plant - accumulator of some metals with broad home range occupying most of Europe (including Ukraine) and suitable for different soil structure, mechanical composition, $\mathrm{pH}$ and moisture conditions $[15,13,14,6]$. 
KALMAR ECO-TECH'03

Bioremediation and Leachate Treatment

KALMAR, SWEDEN, November 25-27, 2003

Willow is a typical component of plants pioneer community appearing on river sands, abandoned towns of Chernobyl zone, industrial grounds and therefore has been used for stabilization of spoil heaps and border of holes in earth surface in Kazakhstan and Russia $[16,17,18,19]$. High ability of metal intake from contaminated soils is proved for S.caprea, S. fragilis, S.viminalis $[6,14]$. Accumulation coefficient is rather high for such metals as $\mathrm{Zn}, \mathrm{As}, \mathrm{Cd}, \mathrm{Sr}$. Willows are plants with high biomass and could be applicable for phytoextraction being no hyper-accumulators. Willow is a plant that could be also used to lower the shallow water level.

Characteristic feature of cattail and reed growing in the condition of wetlands within the environmental impact zone is metal accumulation from water and the bottom. Doubtless effect of high aquatic plants community on industrial waste water cleaning has been proved $[20,21]$.

Plants considered as hyper-accumulators like Alyssum spp., Thlaspi spp., Artemisia spp. could be found among local vegetation in Ukraine, too.

\section{CONCLUSION: OBJECTIVS FOR THE FUTURE}

Soil, water and sediment pollution is a great problem for Ukraine. Pollution is generated by main human activities especially mining, industrial and domestic wastes. It has been recognized that pollution causes troubles for human health and dysfunction in the ecosystem.

Treatment of metal-contaminated soil using traditional methods is either costly or impossible for large areas to be treated. The use of plants for soil remediation is a more economic and environmentally friendly alternative. It could be pointed that some technologies are preferable for the conditions in Ukraine - for the soil in situ treatment: phytostabilization and phytoextraction. Such plants common for Ukraine as willows with high biomass and metal up-taking ability could be applied for the technology. Hyperaccumulators for certain metal extraction could be found among local plants too.

Respective biotechnology has to be applied for treatment of leachate from domestic waste landfills and caused surface and ground waters pollution.

Each application of technology should be evaluated on case-by-case bases and therefore there is a great need for experimental work.

\section{REFERENCES}

[1] Marinich, O.,ed., 1993. Geografichna Encyklopedija Ukrajiny. (The Geographical Encyclopaedia of Ukraine), in 3 vols. 'Ukrajinska Encyklopedija' Publ. House, Kyiv (In Ukrainian)

[2] Ivchenko, A., 1999. Mista Ukrajiny. Dovidnyk (Towns of Ukraine. Reference). NPV 'Kartografija', Kyiv (in Ukrainian) 
KALMAR ECO-TECH'03

Bioremediation and Leachate Treatment

KALMAR, SWEDEN, November 25-27, 2003

[3] Sajet, E., et al., 1990. Geochimija okruzchajuschej sredy (Environmental Geochemistry). 'Nedra” Publ. House, Moscow (in Russian)

[4] - 1987. Metodicheskie ukazanija po otsenke stepeni opasnosti zagrjaznenija pochvy chimitcheskimi veztshestvami [Methodology manual on assessing the level of soil chemical contamination hazard]. Moscow, Ministry of public health of the USSR. - $46 \mathrm{p}$. (in Russian)

[5] Kovalevskij, L., 1991. Biogeochimija Rastenij (Biogeochemistry of Plants). Nauka' Publ. House, Novosibirsk (in Russian)

[6] Boruvka, L., 2002. Phytoremediation of Metal-Contaminated Sites in the Litavka Area and in Czech Republic. In: Proceedings of the NATO ASI « Phytoremediation of Metal-Contaminated Soils» - Třešt, Czech Republic

[ 7] Morel, J.L. 2002. The Aims of the Remediation of Metal-Polluted Soils. Ibid.

[8] Svirenko, L., Vergeles, Ju., Jakovlev, V., 2003. Metals accumulation in soils and vegetation of river valleys in the city of Kharkiv, Ukraine. In: Abstracts book of the $2 \mathrm{~d}$ international conference "Soils of Urban, Industrial, Traffic and Mining Areas", July 911, Nancy, France, pp. 103-104.

[9] Nossova, A., 2003. Organizatsija pererabotki porodnych otvalov kak effektivnyj pyt' reshenija ekologicheskich problem ugledobyvajuschich regionov (Management of spoil bank processing as a way to solve problems of a coal mining region ). M.S. Thesis. Ecology \& Environment Protection. Kharkiv State Academy of municipal Economy, Kharkiv, Ukraine (in Russian)

[10] Kostenko I., Opanasenko, M., 2003. Acid sulfate soils on mine wastes in west Donbass region of Ukrain. In: Abstracts book of the $2 \mathrm{~d}$ international conference "Soils of Urban, Industrial, Traffic and Mining Areas", July 9-11, Nancy, France, pp. 209-210.

[11e] Sahut, C., 2003. Phytoextraction of toxic metals in polluted dredged sediments. In: Abstracts book of the $2 \mathrm{~d}$ international conference "Soils of Urban, Industrial, Traffic and Mining Areas”, July 9-11, Nancy, France, pp. 215-216.

[12] King, R., Royle, A. \& Hamon, B. 2002. Phytoremediation of Contaminated Canal Sediments Dredged from a Canal in Warrington, England. Ibid.

[13 ] Dickinson, N., 2002. Phytoremediation of Industrial-Contaminated Sites Using Trees . In: Proceedings of the NATO ASI « Phytoremediation of Metal-Contaminated Soils» - Třešt, Czech Republic.

[14] Keller, C. 2002. Limitations and Technical Implications of Phytoextraction of Metals at Multi-Metals Contaminated Sites. Ibid 
KALMAR ECO-TECH'03

Bioremediation and Leachate Treatment

KALMAR, SWEDEN, November 25-27, 2003

[15] Vandenhove, H. 2002. Phytomanagement of Sites Contaminated with Radionuclides . In: Proceedings of the NATO ASI " Phytoremediation of MetalContaminated Soils» - Třešt, Czech Republic.

[16] Kuprijanov, A., Grudzinskaja, L. Ispol'zovanije iv pri rekul'tivatsij narushennych zemel' (Recultivation of disturbed lands using willows). In: Rastenija i promyshlennaja sreda (Plants and industrial environment). UralGU Publ. House, Sverdlovsk, Russia (in Russian), p.p.143-148.

[17] Svirenko, L., Spirin, O., Uvarova, G., 2003. Rol vidov ivy v technologijach vosstanovlenija okruzhayuschey sredy.- Materialy konferencij "Falzfeynovskie chtenija" (Willow species as a tool of environment remediation technologes). In: Proceedings of Cherson conference "Falzfein readings"), April 23-25, Cherson, Ukraine, pp. 315-317 (in Russian).

[18] Shilova ,I., 1989. Jestestvennaja rastitel'nost' zavodskich territorij industrial'nogo tsentra (Natural vegetation of works grounds in industrial center). In: Rastenija i promyshlennaja sreda (Plants and industrial environment). UralGU Publ. House, Sverdlovsk, Russia (in Russian), p.p.44-56.

[19] Tjutjunnik, Ju., Bednaja, S.,1998. Izmenenija rastitel'nogo i pochvennogo pokrova v urbanizirovannych landshaftnych zonach otchuzchdenija Chernobyl'skoj AES (Shifts in vegetation and soil cover in urbanized landscapes of Chernobyl NS zone). Preprint NANU, Chornobyl (in Russian).

[20] Svirenko, L., Vergeles, Ju., Spirin, O., 2003. Environmental Effects of Ferrous Slags - Comparative Analyses and a Systems Approach in Slag Impact Assessment for Terrestrial and Aquatic Ecosystems. Chapter 22 in: Approaches to Handling Environmental Problems in the Mining and Metallurgical Regions. - NATO Science Series. IV. Earth and Environmental Sciencese- Vol. 20, pp.e211-229.

[21] Jakubovskij, K., Mjerjezhko, A., Njestjerjenko, N., 1975. Nakopljenije vysshymi vodnymi rastenijami eljemjentov mineralnogo pitanija (Accumulation of nutritive elements by higher aquatic vegetation). In: Biologicheskoje samoochishchjenije i formirovanije kachestva vody. 'Nauka' Publ. House, Moskva (in Russian) 